\title{
Green Banking Concept As A Positioning Strategy To Gain Brand Image
}

\author{
Mohamad Hadi Prasetyo \\ Sekolah Tinggi Ilmu Ekonomi (STIE) Ekuitas \\ hadi.p@ekuitas.ac.id
}

\begin{abstract}
The awareness of environmental preservation is the duty of every human being. In the current business world, all speaks about the concept of green. This paper is aimed at describing the concept of green banking as a positioning strategy to improve the brand image of the company (bank) itself. The method used is a descriptive empirical method. There are lots of strategies undertaken by companies to strengthen their brands. All the things performed by those companies are strategies to strengthen their brands. It is related to the positioning and its positive impact on brand image. Here, the concept of green can be regarded as a "seasoning" to accompany the corporate strategy which is expected to strengthen brand image. This concept is not merely a social activity as a whole, but it leads more to strengthen the positive image obtained by the company. Brand image can be improved. The brand image of a company may improve and its possible positive consequence is that the brand can be the top of mind for customers. Nowadays, customers should be appreciated even more, meaning that their "value" must be raised. This can be used as a guide for companies using the concept of green in their strategies.
\end{abstract}

Keywords: positioning, brand image, green banking.

\section{INTRODUCTION}

In recent times, we often hear about the concept of green banking. When hearing this concept, a thing crosses in our mind is a link between go green concept and banking companies. Go green concept has long been considered by some companies. Lots of companies always campaign that they have implemented or are going to implement the go green. The term "back to nature" is no longer a slogan of theirs. Go green can be done in their various activities. This paper is aimed at describing the concept of green banking as a positioning strategy to improve the brand image of the company (bank).

Has the concept of go green been the new strategy of the companies in improving their image in public? Everything done by the companies is part of their strategy. For example, companies performing CSR or charity work publish this activity, hoping the image of the companies will increase in the community. The companies must be willing to do anything to boost their image in public, where the goal is definitely to be better known and also strengthen their brand. Many strategies undertaken by the companies to strengthen their brand.

When we deeply review the concept of go green, this generally means that the company cares about the environment. Yet, I personally feel that it is not ideally conducted $100 \%$. Why? As we have understood, it is difficult for the company to avoid or even eliminate the use of paper in its daily activity. Not to mention, if we look at companies in big cities, their building architecture may contribute to greenhouse gas effect.

In the other hand, there are some companies that have started performing the concept of Go-Green. Some of the ways they did as the example of go green are, they use recycled paper, they design their building with vines around it, this for sure will have a positive impact on the production of fresh air. Banking world can be used as a new force in building the Go-Green movement. The role of banking world is to be a bridge among investors and stakeholders to develop new regulation related to Go-Green concept. All of these does not eliminate the focus of companies' target market.

If we associate this concept with the brand positioning strategy, the companies implementing go green will become public concern. Some of the things done related to the concept of green banking may result in positive image in public. Society will think that the company (bank), in doing its activities, is concerned about the environment. This is highly considered to boost the positive image or reinforce the "brand" that already exists.

In other words, the public will pay more attention to the company. The public attention will make it easier for the company to increase sales, which certainly will result in positive contribution to the company. It can be said here that the company showing environmental awareness still has an ultimate goal to increase its profits. It is indeed the purpose of all enterprises.

Here we can say that the concept of green banking is a strategy that will lead to strengthen the positioning of the company. Like anything else, if the brand is strong, it is easier for the firm to increase profit. There may be a question, to what extent the concept of green banking will touch the daily life of the company (bank)?

\section{LITERATURE REVIEW}

\section{A. Green Banking}

Green Banking Refers to the banking business conducted in selected area and manner that helps the overall carbon emission reduction of external and internal carbon footprint [1]. The purpose of green banking is to reduce the level of pollution and carbon emission. Bahl (2012) also mentioned that the concept of green banking is also a promotional material of environmental-friendly practices [1]. 
The strategy of green banking itself can be used as a business model, among others are: green banking financial products, paperless banking for carbon footprint reduction, energy consciousness, using mass transportation systems, green building, social responsibility services [1].

The concept of green banking helps to make the future brighter and green because green banking has a direct impact felt by the environment [2]. Banks can also develop more sustainable products, such as environmental, social, or ethical investment funds [3]. Keeping the environment is also the obligation of the financial institution. The investments made must consider the environment preservation and sustainability of the surroundings. "...Encouraging environmentally responsible investments and prudent lending should be one of the responsibilities of the banking sector. This method of finance can be called as "Green Banking" [3].

Ruth A. Sekaryuni (Bank Indonesia), a Research Executive of the Directorate of Banking Research and Regulation of Bank Indonesia, says that green banking is banking concept of doing business based on the principle of sustainability development. As an example, in giving loan and financing, the bank must consider the ecological balance, human welfare, social and cultural development of society. The definition is similar to that issued by the World Bank. According to the World Bank, Green Banking is based on four elements namely nature, well-being, economy and society [4]. By implementing the concept of Green Banking, banking activities in general will not be disturbed. In fact, this will result in both tangible and intangible benefits [5]. The Principles of Sustainable Development ensure that the development done should have a balance on three perspectives, namely Profit (Economy), People (Social), Planet (Eco-Friendly).

Green Banking is an effort done by the banks to make the industries grow green and in the process restore the natural environment [6]. It also said that the concept of green banking itself is very useful for banks, industry-wide and the economy in general. Green bank is a financial institution that gives priority to the sustainability in its business practices. In the future, the world of business will not work without applying the environmental principle because banks will not be willing to support that kind of business [4].

\section{B. Positioning}

Positioning becomes important to grow in terms of business sector. Companies struggle in order their brands to be remembered, prioritized by prospective customers, loved and purchased (consumed) whenever needed. The concept of brand placement strategy has been long time ago and it continues to evolve with the development of human civilization [7].

Company owning the brand must know the position of the brand in the mind of customers. Positioning done by the company reflects the product itself. Making a brand differ from other brands is a perception and feeling of customers about the attribute of the product as well as its performance.
Placing the brand in the mind of customers has always been the serious effort and it is done to build the strength of the brand. Brand management is all about efforts done related to how to place brand into the customer's minds among the brands that already exist. Brand strategy is a process in which the offer is positioned in the mind of customers that will result in useful perception [8].

Positioning is not what you do to the product but what is in the mind of your customer to be. This is done by the company to place the product into the mind of customers.

Positioning can also be said as a process in which the results lead to the product positioning. Kotler in Surachman (2008) also says that something which should be taken first is how we design a positioning, not setting the brand [8].

Positioning is the act of designing brand offering and corporate image so that these occupy a position in the mind of customers as well as distinguish the firm from the competitors. Brand Positioning is an effort to communicate the reality of the brand to customers, but not all of reality can be communicated to the customer [8].

Thus, the brand placement of the company is to establish a brand image of the company in the perspective of society [9]. The placement of the brand is not just advertising or such, but the totality of the overall marketing program including marketing activities such as integrated marketing communication. This is conducted to establish brand image [9]. This is because the positioning that will be placed in customer's mind must also be supported by differentiation.

In this case, the company (bank) must also be able to see any difference (in concept) that will be done. Finally, we need to remember that all things done by the company is to boost the image or to strengthen the existing ones. With the differentiation done by the company (the presence of positioning), this can be achieved.

\section{Brand Image}

Arslan \& Altuna (2010) state that brand is the most important one and can also be the most important asset for the owner of the company [10]. This is how companies can get the image of a brand. The image of a brand is a set of unique associations to be created or maintained by brand holder [8]. The association is the thing which tells the customer what is actually promised by the firm. However, the company may want something but the results are not always the same as expected. Association of a brand (brand image) can set an influence on customers' willingness to make buying [11].

According to Kotler, et al, the brand image is the perception and beliefs held by customers, as reflected in the customer associations held in memory [12]. Brand image is part of the brand itself that can be recognized, but difficult to describe verbally. Strong brand image can provide a number of advantages and unique capabilities which are difficult to imitate. This also increases customer loyalty and repeats the purchase of customers. Aside from them, there are many 
other positive inputs that can be received by the company [13]. Developing a strong image requires creativity and hard work. The image can not be implanted in the public mind overnight or disseminated through the media only. Instead, the image must be delivered through any means of communication available and deployed continuously. Brand image has been conceptualized and operationalized in Several ways [14].

The brand image is related to belief and attitude toward a brand preference and customers with a positive brand image are more likely to have this preference. Hence the usefulness of the ads is to build a positive image of the brand. Another benefit of a positive image is, the company can develop a product line by utilizing the positive image which has been formed in the previous product brand. Image can be defined as belief, idea and impression embraced by someone about an object in which a person's attitude and action towards an object will depend on this image [15].

Affecting the customer's positive image to the brand is a remarkable thing. Because through this, the brand can last longer as it has become a positive image in the market. Appropriate strategy to influence customer brand image is the product positioning. In positioning the brand, marketers must first have a product concept that can communicate the desired benefits through advertising and the use of media reaching the target market. The brand image can be regarded as a kind of association that comes to mind when considering a particular brand.

\section{RESEARCH METHODOLOGY}

This paper is aimed at describing the concept of green banking as a positioning strategy to improve the brand image of the company (bank) itself. Where the context is a company (bank) uses the concept of green as its positioning strategy. This research type is descriptive. Descriptive research is a research aiming at obtaining an overview of the characteristics of the existing variables. Descriptive research is carried out to know and explain the characteristics of the variables examined in a situation [16].

\section{RESULTS AND DISCUSSION}

In the banking world, the emergence of the concept of green banking has been a hot topic since 2002. Many people question, can a financial institution have a strategy which is concerned about the environment?

Bank of Indonesia issued a policy to encourage the company to be in line with the global trend which is to incorporate the aspect of environmental protection. This enables banking sector to have a clear rule and policy in supporting sustainable development. This policy has been the liability to be implemented by Indonesian banking industry. This is because Indonesia is the country which has enormous natural resources. Besides, the government has the power to influence the creation of a system of financial institutions (banks and non-banks) which care about environmental issues.
The concept of green banking done by the company can also be regarded as a strategy of "green marketing". This strategy is undertaken to strengthen brand positioning of the firm. But here, not all strategies are really green. But the company continues to improve the concept of green banking. The point is that the company has shown its concern for the environment. The concept of "green" applied by the company is used as a strategy to seize the "heart share" of wide customers. Some examples are the placement of some greenery in the work-space, minimizing the use of paper, or may be in the more extreme one is planting vines on the outside wall of the building intended to minimize the greenhouse effect. Another activity that can be undertaken by bank is to use the layout design of the front office which shows the care about the environment.

In terms of improving bank's risk management capability, banks are required to produce portfolio that leads to environmental awareness. Here we can see that the cost (spending) incurred by the bank is not only to assist business sectors in terms of lending, but also to raise the awareness of environmental preservation. Therefore, there are two things that can be achieved by the bank, first is to finance entrepreneurs to improve their businesses which are environmentally friendly, second is to play an active role in environmental conservation. In other words, banks have to be be firm and selective in providing financial assistance, especially to some parties proven to cause environmental destruction.

Banks' ultimate purpose of this activity is to improve the image in the mind of their customers. Any bank can have a good reputation as an environmentally friendly bank because of its relentless and serious effort the environmental preservation. For some people it might be trivial, but if we further examine the importance of environmental health, our hearts will certainly be touched to play an active role in environmental conservation.

In the business world, there are still more people who have less concern about nature preservation. Because they think that it is wasting. The cost of the environmental preservation is much fewer than that the firm earns. This actually should make the firm think that the spending is not to enrich any particular person. But this is for the sake of the next generation. In this case, the companies having higher level of social awareness will certainly do the concept of green because they are aware of the importance nature preservation.

Green concept is not simply a social activity as a whole, but rather something that leads to strengthen the positive image of the firm. Brand image of the firm may increase. The possible positive consequence is the brand can be the top of mind. Yet, all these things do not go smoothly or easily. All these things also depend on the core services that the firms have. Companies still have to run their core business and at the same time apply the concept of green. It will be useless thing if the company is concerned about the concept of green but the service quality does not improve.

In this case, the concept of green can be regarded as a "seasoning" to accompany firm strategies which are 
expected to strengthen their brand image. There are still many customers who have not been aware of the concept of green. This is because in their daily life, they have not implemented or are not aware of the environmental preservation. There is a difference between 'to know' and 'to be able'. Knowing stops in the mind, without the power to undertake something. This differs from 'to be able' which means to be aware of what is done with regard to the concept of environmentally friendly activity. And this will result in huge benefit. This is not only any particular person, but for the whole of mankind. It is also used as a reason by some companies implementing this concept. Especially in banks where a lot of interactions with public in general occur. An example is to put green plants around the counter and waiting area where the customers can get more fresh air. This will prevent them from boredom, too. Clean and fresh air in a certain room can be associated with air circulation and additional oxygen. These can also relax the customers' emotion.

Many people think that in their daily activities, banks definitely use a lot of papers and as we know this can damage the environment. But there are now many banks which reduce the use of paper. For instance, the ATM machine is programmed to ask the customers whether to print the balance or just display on the screen. There are also banks whose ATM machines have a program to be able to print multiple transactions in just one print out. These things are examples of caring the environment because the banks are able to reduce the use of paper.

In other words, customers feel to be served indirectly by the atmosphere in the building or office. Currently, companies are competing not only to satisfy the needs and desires of customers, but also to impress customers. The concept of green done by the company can impress customers. This can be attributed to the concept of "wow selling" introduced by Hermawan Kartajaya that customers who had been "aha" can turn into "wow".

Differentiation done by companies related to the concept of green can result in positive image. This can build or strengthen the existing ones. With the strategy of positioning done based on differentiation, customers will surely feel and see the positive value from the company. And if this activity continues over time (sustains), the company can be said to have "moved" and can also be said to have a long-lasting greatness. The concept of "jump to second curve" introduced by Jim Collins, can be used as an analysis tool. This states that the companies (banks) performing the green concept have a vision that far ahead so that the they will not "decline".

Something to be questioned is, does a company doing the concept of green simply follow others? Whereas the conservation of nature is our responsibility as inhabitants of the earth. If the company does not want to be said as a follower, it has to engage in innovation and improvisation of its green concept. The point here is a clear differentiation and originality of what is done by the company. I am always reminded of Jim Collins words that good is the enemy of great. This should be considered by all companies who want to become leader and get positive image from customers.
Regarding to this, the implementation of green concept should have an element of differentiation from other companies. By implementing this, it is very likely that the company can increase the positive value in the perspective of customers.

As a result, with increased or strengthened image, the brand will also increase. The value of the company will definitely increase, too. We need to think how to maintain our products to be in line with the grand strategy related to the concept. Moreover, it is done to attain heart share which the output is to make the company become the "top brand" achiever. The ultimate goal is to build a long lasting greatness of the firm.

\section{CONCLUSIONS}

Banking world exists because of public demand. With the banks, the community is helped financially to improve the business and also their lives. Therefore, companies (banks) must also "serve" with full heart to be able to get a "position" in the view of customers.

Serving wholeheartedly can result in "concern" from customers at large. By doing so, customers are not only satisfied but also impressed by what is done by the company. Indeed, it is better to impress than just to satisfy the customers. Things to impress customers are done through the strategy of green in various aspects. In the case of banking industry, this is not only to increase the service because this is already a program to satisfy customers. Currently customers need to be valued. This can be done through the concept of green in every aspect. The thing to remember is that the concept of green is done not because of going with the stream (following other companies). Indeed, the campaign of green has been widely known. So one thing to do now is to make or have difference in the strategy concept. It is highly associated with creativity and imagination.

\section{REFERENCES}

[1] Bahl, S. (2012). Green Banking-The New Strategic Imperative. Asian journal of research business economics and management. Vol 2 (2). P.G. Department of Commerce \& Management, Arya College, Ludhiana.

[2] Sharma, N., et all. (2013). A study on customer's awareness on Green Banking initiatives in selected public and private sector banks with special reference to Mumbai. IOSR Journal of Economics and Finance (IOSR-JEF) e-ISSN: 2321-5933, p-ISSN: 2321-5925 PP 28-35. 7th International Business Research Conference. Indian Education Society's Management College and Research Centre. www.iosrjournals.org.

[3] Biswas, N. (2011). Sustainable Green Banking Approach: The Need of the Hour. Volume-I, No.1, January - June, Business Spectrum.

[4] Ardiansari, A. (2012). Green Banking: Prioritas Pada Sustainability Dalam Praktik Bisnisnya. Fakultas Ekonomi Universitas Negeri Semarang. 
[5] Ayu, A. N. F., \& Anityasari, M. (2013). Analisis Implementasi Green Banking pada PT. Bank X (Persero) Tbk.jurnal teknik pomits vol. 1, no. 1, (2013) 1-6. Jurusan Teknik Industri, Fakultas Teknologi Industri, Institut Teknologi Sepuluh Nopember (ITS). Surabaya.

[6] Bhardwaj, B. R., \&Malhotra, A. (2013). Green Banking Strategies: Sustainability through Corporate Entrepreneurship. Greener journal of business and management studies. Greener journals ISSN: 22767827 Vol. 3 (4), pp. 180-193, May 2013. India.

[7] Adiwijaya, M., \& Djati, P. S. (2006). Analisa Strategi Penempatan Merek Sebagai Bagian dalam Komunikasi Pemasaran Terpadu. Jurnal Manajemen. Universitas Kristen Petra. Surabaya.

[8] Surachman, S. (2008). Dasar-Dasar Manajemen Merek, Alat Pemasaran untuk Memenangkan Persaingan. Malang: Bayumedia Publishing.

[9] Ma'ruf, H. (2006). Pemasaran Ritel. Jakarta: PT. Gramedia Pustaka Utama.

[10] Arslan, F. M., \& Altuna, O. (2010). The Effect of Brand Extensions on Product Brand image. Journal of Product \& Brand Management. 19(3), 170-180. School of Economic and Administrative Sciences, Marmara
University, Istanbul. Retrived from Emerald Group Publishing Limited. Turkey.

[11] Febriani, K. (2008). Program Loyalitas Pelanggan dalam Meningkatkan Citra Merk. Jurnal Bisnis \& Manajemen. 9(1), 39-49.

[12] Kotler, P., et all. (2009). Marketing Management, An Asian Perspective (5th Ed.) Singapore: Prentice Hall.

[13] Faqih. (2008). Pengaruh Strategi Positioning Produk terhadap Citra Merek pada Produk Sunsilk Clean \& Fresh Shampoo. Skripsi pada Fakultas Ekonomi Jurusan Manajemen Universitas Islam Negeri (UIN) Malang: tidak diterbitkan.

[14] Sondoh Jr, S. L., et all. (2007). The Effect Of Brand image On Overall Satisfaction And Loyalty Intention In The Context Of Color Cosmetic. Asian Academy of Management Journal, Vol. 12, No. 1, 83-107, January 2007. Malaysia.

[15] Sulaksana, U. (2007). Integrated Marketing Communication, Teks dan Kasus. Yogyakarta: Pustaka Pelajar.

[16] Sekaran, U. (2006). Research Methodology for business, (fourth Ed). Jakarta: Salemba Empat Publishing. 